\title{
Elimination of toluene from venous blood and adipose tissue after occupational exposure
}

\author{
G NISE, ' R ATTEWELL ${ }^{2}$ S SKERFVING, ${ }^{2}$ P $\emptyset$ RB ÆK ${ }^{\prime}$
}

From the Departments of Occupational Medicine, ${ }^{1}$ Lund University, Malmö General Hospital, S-214 01 Malmö, and University Hospital, ${ }^{2}$ S-221 85 Lund, Sweden

ABSTRACT In a group of 37 rotogravure printers a close correlation $\left(r_{s}=0.78\right)$ was found between the time weighted toluene exposure during a five day working week (range $8-416 \mathrm{mg} / \mathrm{m}^{3}$, median 75) and the concentration of toluene in subcutaneous adipose tissue (range $1 \cdot 1-20.7 \mathrm{mg} / \mathrm{kg}$, median 3.8 ). After exposure ceased, the elimination of toluene was followed up in 11 subjects. The toluene concentration in venous blood decreased non-linearly and the elimination curves contained at least three exponential components. The first two had median estimated half times of nine minutes and two hours respectively. The third component, with a median half time of 90 hours, reflected the decline in adipose tissue, which had a median half time of 79 hours (range 44-178). The study showed protracted endogenous toluene exposure from adipose tissue depots long after the end of exogeneous exposure. The observations also suggest that the blood toluene concentrations on Monday mornings might be used as an index of the exposure in the previous week.

A knowledge of the kinetics for eliminating toluene from venous blood and adipose tissue is important in evaluating toxicity and for planning biological monitoring. The concentration of toluene in venous blood (B-toluene) is used for the biological monitoring of occupationally exposed workers. ${ }^{2}$ The elimination of toluene from arterial and venous blood has been investigated in experimentally exposed subjects, showing a rapid decrease of toluene in both arterial and venous blood. ${ }^{3-5}$ After 60 minutes, only $9 \%$ was left in alveolar blood and $23 \%$ in venous blood. ${ }^{4}$ The elimination of toluene from subcutaneous adipose tissue has also been studied in voluntary subjects exposed under experimentally controlled conditions. The half time for toluene in subcutaneous adipose tissue ranged between 0.5 and $2 \cdot 7$ days $(12-64 \cdot 8 \mathrm{~h}){ }^{6}$

Little is known, however, about the elimination of toluene in occupationally exposed subjects. In a previous study of plastic processing workers an accumulation of toluene in the blood during a working week was found at an exposure level of 184-332 ppm $\left(700-1270 \mathrm{mg} / \mathrm{m}^{3}\right){ }^{7}$ Brugnone et al suggest an accumulation at a mean exposure level of $146 \mathrm{mg} / \mathrm{m}^{3}$. We have previously shown an accumulation of toluene during a working week at exposure levels well below the current Swedish TLV $\left(300 \mathrm{mg} / \mathrm{m}^{3}\right)$, which suggests a long half life. ${ }^{2}$

\section{Accepted 6 June 1988}

In the present investigation the association between toluene in environmental air and subcutaneous adipose tissue was studied in occupationally exposed subjects. Toluene elimination was followed up in blood during a weekend and in blood and adipose tissue during a week's holiday.

\section{Material and methods}

SAMPLING STRATEGY

Sampling 1-Environmental air was monitored during a five day working week in two rotogravure printing factories. Samples of subcutaneous adipose tissue were taken from the workers towards the end of the week. Biopsy specimens were taken directly after work ( 25 on Thursday, 14 on Friday).

Sampling 2-To investigate elimination 11 rotogravure printers voluntarily took part in samplings 2 and 3 . Fast elimination from venous blood was studied during a weekend. Blood was sampled directly after work and then after 10, 20, 40, 60, 120, 180,240 , and 360 minutes. Two further samples were taken 21 and 72 hours after exposure ceased.

Sampling 3-Elimination from adipose tissue and the slow decline in venous blood was studied during a week's holiday. Sampling was performed directly after work and then after 63 and 135 hours without exposure. For the 11 participating subjects the amount of body fat was also determined by means of skeletal 
measurements according to the method described by von Döbeln. ${ }^{89}$

\section{SUBJECTS}

The exposed subjects in sampling 1 consisted of 37 male printers exposed to toluene for 2-43 years (median 23). They were aged from 22 to 62 (median 45). In samplings 2 and 3 the group examined consisted of 11 male printers exposed for 13-36 years (median 24). They were aged from 30 to 62 (median 47).

The printers' state of health, use of drugs, smoking habits, and alcohol consumption were checked with a medical examination and a detailed interview.

\section{VENOUS BLOOD SAMPLES}

Blood was sampled in heparinised tubes. The samples were analysed with the head-space technique, using ethylbenzene as an internal standard, on a gas chromatograph equipped with a flame ionisation detector (FID) (Varian model 3700). Standards were made from venous blood to which a known amount of toluene had been added. The detection limit was 0.01 $\mu \mathrm{mol} / \mathrm{l}$. The precision of the method was $4 \%$, both at B-toluene of 0.20 and $3.8 \mu \mathrm{mol} / 1$.

\section{SUBCUTANEOUS ADIPOSE TISSUE SAMPLES}

Skin was penetrated by a scalpel without use of local anaesthetic in the upper lateral gluteal region. Subsequently, biopsy specimens were obtained by a lance shaped needle with dimensions $2.0 \times 80 \mathrm{~mm}(\mathrm{KN}$ 1480 W, Terumo Europe NV, 3030 Leuven, Belgium). The needle was connected via a luer lock to a $50 \mathrm{ml}$ syringe with a glass barrel and plunger (B-D Yale, Becton, Dickinson \& Co).

The concentration of toluene in adipose tissue was determined by gas chromatography after evaporation of the solvent at $150^{\circ} \mathrm{C}$ into nitrogen $(1 \mathrm{ml} / \mathrm{min})$ which was continuously exchanged. ${ }^{10}$ The evaporation lasted 30 minutes and the gas was collected into $30 \mathrm{ml}$ all glass syringes. The gas samples were analysed by a gas chromatograph (Carlo Erba model 4160) equipped with a quartz capillary column DB-1701 (length $30 \mathrm{~m}$, inner diameter $0.25 \mathrm{~mm}$ ). The toluene concentrations were calculated on the basis of standard air samples with known toluene concentrations. The error of the method for single determinations was found to be within $11 \%$ of the mean value of ten duplicate determinations with different puncture channels and the concentrations ranging from 0.5 to $10.2 \mathrm{mg} / \mathrm{kg}$. To obtain reliable results, blood contaminated specimens or those weighing less than $10 \mathrm{mg}$, or both, were excluded. The mean loss of weight during evaporation was $8 \%$ (range $1-18 \%$ ).

The specificity of the analysis of toluene in body fat has been checked in two ways. Firstly, small amounts of pure toluene were added to the nitrogen after evaporation of the tissue. No difference in retention
Nise, Attewell, Skerfving, rrbak $_{\overline{2}}$

time was found for the evaporated and added toluenez Secondly, biopsy specimens from one person con $\mathbb{D}$ tributing the exposure measurements were taken. before and after visiting a toluene contaminated areas Toluene was only found in samples taken after visitinछ the plant.

\section{ENVIRONMENTAL AIR SAMPLES}

The environmental concentration of toluene wa estimated by personal sampling (sampling 1). The workers wore a personal sampler with which samples were continuously taken from the ambient air at 30 minute intervals (the Linder Gaspirator, Instrumenth AB Lambda, Sweden). The sampler sucked air fromg the breathing zone through a Teflon capillary tube int $\$$ a $30 \mathrm{ml}$ all glass syringe. " The toluene content of thes air was immediately determined with a portable gass chromatograph equipped with FID (AID, model 511) Standard gases were prepared by adding known amounts of toluene into a glass bottle with a knowrs volume of clean air. The error of the method, calculated from 25 double determinations ranging fromf 67 to $335 \mathrm{mg}$ of toluene $/ \mathrm{m}^{3}$, was within $1 \cdot 1 \%$ of the mean value.

\section{Data analysis}

The decreasing levels of B-toluene in each subject were fitted as a three compartment exponential model- $\overline{0}$ that is, a linear combination of three exponentials wition different rate coefficients (and thus half times). The non-linear regression procedure of the BMDP pack $\overrightarrow{\overrightarrow{0}}$ age (P3R) was used. It uses the iterative Gauss 3 Newton algorithm. ${ }^{12}$ Owing to the relatively shoro follow up (sampling 2), the half time for the slowesp compartment was estimated separately, using datî collected over an independent and longer period (sampling 3) and held fixed in the three compartments model. Two parameters were estimated for each. compartment: an elimination rate, transformed and quoted as the half time $t \frac{1}{2}(1), t \frac{1}{2}(2)$, and $t \frac{1}{2}(3)$ and the amount corresponding to each compartment $Y(1), \overrightarrow{6}$ (2), and Y (3).

Associations were investigated with Spearman' rank correlation coefficient. All $\mathrm{p}$ values are one tailed

\section{Results}

\section{AIR LEVELS}

In all we have exposure data for seven weeks. The ambient air level ranged from 8 to $416 \mathrm{mg} / \mathrm{m}^{3}$ (media 75). For the 11 subjects voluntarily taking part if samplings 2 and 3 the time weighted exposure for the week, based entirely on measured exposure levelso ranged from 35 to $246 \mathrm{mg} / \mathrm{m}^{3}$ (median 115).

TOLUENE IN VENOUS BLOOD

B-toluene was also measured in 21 unexposed work 
ers; all had concentrations below our detection limit $(0.01 \mu \mathrm{mol} / \mathrm{l})$. The blood in six of those who smoked, however, contained a trace of a compound with the same retention time in the chromatogram as toluene.

At the end of the exposure after the last shift on the Friday, the median B-toluene in sampling 2 was $2 \cdot 3$ $\mu \mathrm{mol} / 1$ (range $1.4-4.4$; fig 1 ). In sampling 3 the corresponding value was $1.0 \mu \mathrm{mol} / 1$ (range $0.22-1.9$; fig 1).

The decrease of toluene was non-linear. Furthermore, the decay did not display a simple exponential pattern. After 63 hours (sampling 3), the median Btoluene was $0.12 \mu \mathrm{mol} / 1$ (range 0.03-0.59). After 135 hours toluene was still present in blood $(0.06 \mu \mathrm{mol} / \mathrm{l}$, range $0 \cdot 02-0 \cdot 17)$. In sampling 2 the median B-toluene after 21 hours was $0.30 \mu \mathrm{mol} / 1$ (range $0 \cdot 18-0.56$ ) and after 72 hours $0 \cdot 16 \mu \mathrm{mol} / 1$ (range $0.05-0.24$ ).

The median half time for the slow elimination ( $t \frac{1}{2}$ (3)), calculated from the blood samples at 63 and 135 hours in sampling 3, was 90 hours (range 50-324). These individual estimates of the slow elimination of toluene from blood were used for calculating the faster decline. A model with three exponentials showed a better fit than one with two. Convergence was achieved after between 13 and 22 iterations for all subjects. The results of the kinetic calculations for the elimination of toluene in blood are listed in the table. The fastest component had a median estimated half time of nine minutes. From the estimates of the intercept parameter (Y (1)), this compartment constituted a median of $35 \%$ (range 20-70) of the maximum B-toluene at the end of exposure. The median half time of the intermediate component was two hours and accounted for the elimination of a median of $42 \%$ (range 22-63) of the tolueise. The slow component corresponded to a median of $17 \%$ (range 3-26).

\section{TOLUENE CONCENTRATIONS IN SUBCUTANEOUS}

\section{ADIPOSE TISSUE BIOPSY SPECIMENS}

At the end of the exposure, the toluene had declined in adipose tissue biopsy specimens (fig 1). In one subject the fat toluene concentration had increased between

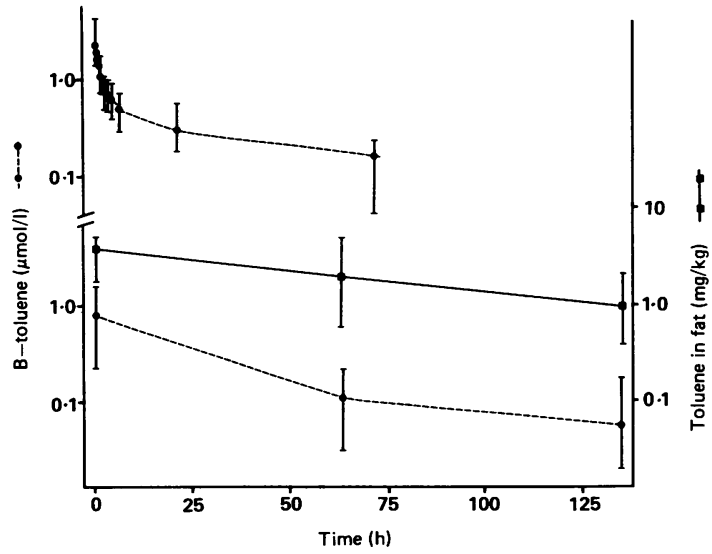

Fig 1 Elimination of toluene: concentrations (medians and ranges) from venous blood (circles) and subcutaneous adipose tissue (squares) after end of exposure.

Friday and Monday. He denied exposure during the weekend. We could not explain the increase by analytical error, thus there had probably been an exchange of his samples. Accordingly, they were excluded from further calculations. The median of the estimated half times for eliminating toluene from adipose tissue was 79 hours for the remaining 10 subjects (range 44-177).

The toluene concentration in adipose tissue taken directly after work on the Thursday and Friday (sampling 1) was associated with the workers' mean exposure in the previous week (fig 2). Spearman's correlation coefficient was $r_{s}=0.780, p<0.00001$ $(n=37)$. The subject marked with an asterisk in fig 2 had a high exposure the day before sampling, but the exposure level could not alone explain his high concentration in both venous blood and adipose tissue.

\section{ASSOCIATION BETWEEN FAT AND BLOOD \\ TOLUENE CONCENTRATIONS}

Comparing elimination of toluene from adipose tissue with the decrease corresponding to the slow compon-

The kinetics of the decrease in toluene in blood after the end of exposure in 10 workers. $T \frac{1}{2}(1), t \frac{1}{2}(2)$, and $t \frac{1}{2}(3)$ denote the half times for different components in a three compartment exponential model; $Y(1), Y(2)$, and $Y(3)$ denote the $Y$ intercepts of the corresponding compartments. $R^{2}$ denotes the goodness of fit (perfect fit $\left.=1 \cdot 0\right)$

\begin{tabular}{|c|c|c|c|c|c|c|c|}
\hline Subject No & $t \frac{1}{2}(1)(\min )$ & $Y(1)(\mu \mathrm{mol} / \mathrm{l})$ & $t \frac{1}{2}(2)(h)$ & $Y(2)(\mu \mathrm{mol} / \mathrm{l})$ & $t \frac{1}{2}(3)(h)$ & $Y(3)(\mu \mathrm{mol} / \mathrm{l})$ & $R^{2}$ \\
\hline $\begin{array}{r}1 \\
2 \\
3 \\
4 \\
5 \\
6 \\
7 \\
8 \\
9 \\
10\end{array}$ & $\begin{array}{c}29 \\
10 \\
4 \\
13 \\
<0.01 \\
8 \\
<0.01 \\
29 \\
5 \\
13\end{array}$ & $\begin{array}{l}1.6 \\
1.6 \\
1.4 \\
0.8 \\
0.4 \\
0.7 \\
0.5 \\
2.8 \\
0.3 \\
1.1\end{array}$ & $\begin{array}{r}10 \\
2 \\
1 \\
2 \\
1 \\
1 \\
2 \\
6 \\
1 \\
3\end{array}$ & $\begin{array}{l}0.6 \\
0.9 \\
2.3 \\
0.9 \\
1.1 \\
0.9 \\
0.7 \\
0.9 \\
0.9 \\
1.0\end{array}$ & $\begin{array}{r}140 \\
59 \\
50 \\
57 \\
57 \\
85 \\
194 \\
324 \\
123 \\
94\end{array}$ & $\begin{array}{l}0.07 \\
0.3 \\
0.6 \\
0.6 \\
0.3 \\
0.5 \\
0.2 \\
0.2 \\
0.2 \\
0.5\end{array}$ & $\begin{array}{l}0.988 \\
0.992 \\
0.995 \\
0.994 \\
0.987 \\
0.991 \\
0.979 \\
0.998 \\
0.983 \\
0.987\end{array}$ \\
\hline
\end{tabular}




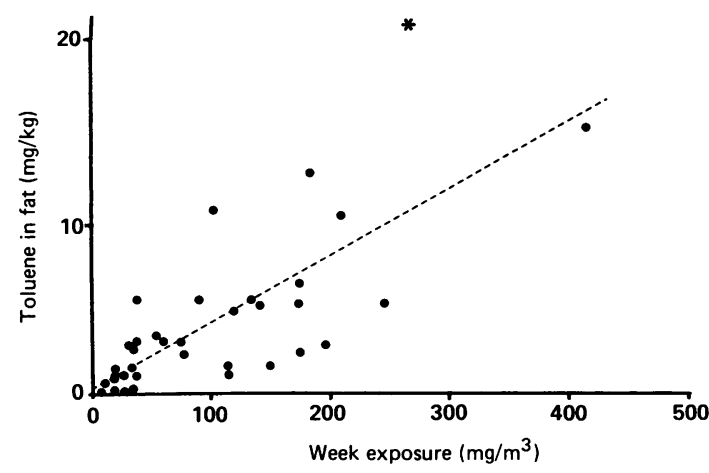

Fig 2 Association between time weighted toluene exposure during working week and toluene concentration in subcutaneous adipose tissue at end of week $\left(r_{s}=0.78\right.$, $p<0.00001)$. Subject marked with an asterisk had particularly high exposure on day before sampling.

ent in blood (median half times $79 v 90$ ) indicates that the B-toluene after about 70 hours exposure free time reflects the elimination from adipose tissue (fig 1). The association between the slow half times estimated in blood ( $\left.t \frac{1}{2}(3)\right)$ and the estimated half times for the toluene elimination from adipose tissue is shown in fig $3\left(r_{s}=0.46, p=0.09 ; n=10\right)$. For six of the ten subjects, the $t \frac{1}{2}(3)$ in blood are within two standard deviations of the half time of toluene in adipose tissue.

There is a weak positive association between the estimated proportion of toluene in blood corresponding to the slow elimination and the concentration of toluene in adipose tissue (70 hours after work in sampling 3) multiplied by the amount of body fat, expressed as percentage of body weight $\left(r_{s}=0.47\right.$, $p=0.08)$. Using instead the B-toluene 70 hours after exposure strengthened the association (fig $4 ; r_{s}=0.82$, $\mathrm{p}=0.007)$.

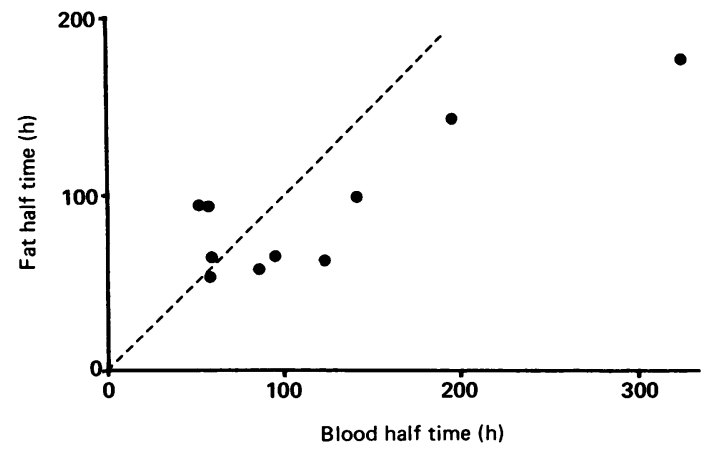

Fig 3 Association between half times for slow elimination from blood $t \frac{1}{2}$ (3) and half times for decrease in subcutaneous adipose tissue $\left(r_{s}=0.46, p=0.09\right)$. Line with unit slope is marked.

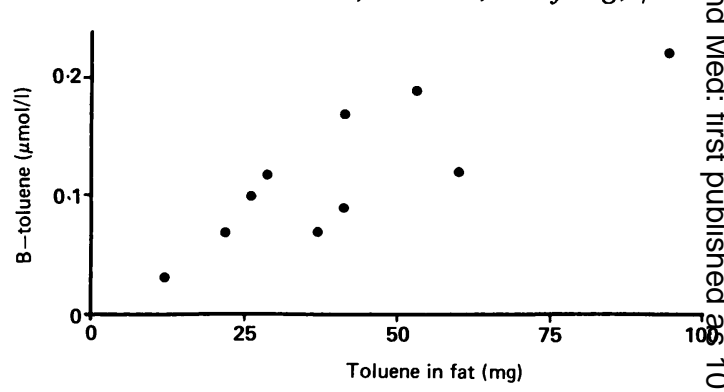

Fig 4 Association between blood toluene concentrations on $\overrightarrow{\vec{\omega}}$ Monday after an exposure free weekend and estimated amount of toluene in subcutaneous adipose tissue; $r_{s}=0.82$, $p=0.007$.

\section{Discussion}

We found that the elimination of B-toluene in occupationally exposed subjects may be described by a model containing at least three components. We을 cannot correctly describe the fast elimination directlyafter the end of exposure. We had a lapse of time from ${ }_{-}$ end of exposure until the first blood sampling because the subjects had first to walk for a few minutes to a nearby toluene free location. In studies performed ino exposure chambers a fast decrease of B-toluene has been shown during the first minutes without exposure. Only $23 \%$ of the initial concentration was left as soons as one hour after the end of exposure. ${ }^{413}$ Thus ouro initial B-toluene concentrations are not fully compara-0 ble with the data obtained in the chamber studies. Weo found a median of $50 \%$ remaining one hour after $\vec{B}$ exposure had ceased. Thus we underestimated the trues initial decline and correspondingly somewhat overestimated the other two components.

The difference between B-toluene directly aftero work in samplings 2 and 3 is probably due to the approaching holiday at sampling 3 . The printerso reported that they had lower exposure during their last $\mathrm{B}$. hours of work just before their holiday. Consequently B-toluene had already started to decrease during the last working hours.

An important finding in the study is the presence of a slow component in venous blood, which had ao median half time of 90 hours. This is in agreement with our previous estimates of 72 hours (range 32-92). ${ }^{2}$ Theos slow compartment corresponded to a median of $14 \%$ of the total B-toluene at the end of the exposuren Indeed, after 21 hours we measured $13 \%$ of the initia B-toluene, which is also in agreement with our previous findings ${ }^{2}$ and is also in reasonable agreemento with the $7 \%$ found by Brugone et al. ${ }^{1}$ Hence, during aos weekend the slow compartment should dominate the B-toluene concentration already after 24 hours.

The median estimated half time for elimination of toluene from adipose tissue was 79 hours. This is in 
good agreement with the findings in an experimental study by Carlsson and co-workers, in which the subjects were exposed for only two hours but at higher air levels. ${ }^{6}$ We found an association between the slow elimination $\left(t \frac{1}{2}(3)\right)$ from blood and the half time for the decrease in subcutaneous fat. The elimination from blood, however, seems to be somewhat slower than that from subcutaneous fat. The discrepancy might be due either to an overestimate of the half time in blood because of a not recorded rapid component or to a decay of the biotransformation of toluene towards the end of the study period. After 70 hours without exposure, we found a significant association between the concentration of toluene in subcutaneous fat and in blood. Thus we have strong evidence that the easily monitored slow elimination from blood reflects the disappearance of toluene from adipose tissue.

The prolonged presence of toluene in blood means that there is an endogenous exposure from the adipose tissue depots, which continues for a long time after the end of a workshift. Thus the nervous system is subjected to the pharmacological effects of toluene during nights, weekends, and even during the first part of holidays. One may speculate whether this prolonged endogenous exposure is important in the development of chronic toxic effects.

The concentration of toluene in subcutaneous adipose tissue towards the end of the working week reflects the exposure during the preceding week. Some values appeared to be outliers (fig 2). The explanation may be that an occasional high exposure during the sampling day or the day before, or both, gives an increase of toluene in body fat, whereas the time weighted exposure for the week is affected to a smaller extent. Despite the close correlation between the concentration of toluene in fat and the air level, the fat biopsy method will not be commonly used for biological monitoring, as sampling is too traumatic for routine use. Instead, preshift B-toluene in Mondays might be used as a biological index for the exposure during the previous week. This suggestion, however, has not yet been tested.

The large interindividual variation in the elimination rates from blood is an important observation. It may be partly due to the lapse of time between end of exposure and sampling but is probably also due to genetic or life style factors, or both. The oxidative metabolism of some xenobiotics is known to vary substantially between individuals. ${ }^{14}{ }^{15}$ Smokers eliminate toluene faster than non-smokers. ${ }^{16}$ In the present study, however, the four current smokers had half times evenly distributed within the group range. Alcohol intake during exposure is known to influence the distribution and elimination of toluene. ${ }^{17} 18$ Our subjects were asked not to drink alcohol during the sampling period and traces of ethanol were found in only a few samples.

The varying half times might influence the possibility of evaluating exposure through biological samples. Thus there is a risk of overestimating the environmental exposure for a subject with a long half time. Protracted endogenous exposure may still mean an increased risk for developing adverse effects from the exposure to toluene. Thus the biological sample may be a good index of risk.

The study was supported by a grant from the Swedish Environment Fund (ASF 86-0913). We thank Ms B M Jakobsson and Ms G Nilsson for skilful technical help and Professor Birgitta Haeger-Aronsen, Dr Ulf Hjortsberg, Dr Jörn Nielsen, and Ms G Persson for help with the biological sampling.

Requests for reprints to: Gun Nise, Department of Occupational Medicine, Karolinska Hospital, S-104 01 Stockholm, Sweden.

\section{References}

1 Brugnone F, De Rosa E, Perbellini L, Bartolucci GB. Toluene concentrations in the blood and alveolar air of workers during the workshift and the morning after. $\mathrm{Br} J$ Ind Med 1986;43: 56-61.

2 Nise G, Ørbæk P. Toluene in venous blood during and after work in rotogravure printing. Int Arch Occup Environ Health 1988;60:31-5.

3 Åstrand I, Ehrner-Samuel H, Kilbom A, Ǒvrum P. Toluene exposure I. Concentration in alveolar air and blood at rest and during exercise. Work Environ Health 1972;9:119-30.

4 Carlsson A. Exposure to toluene. Uptake, distribution and elimination in man. Scand J Work Environ Health 1982;8:43-55.

5 Veulemans H, Masschelein R. Experimental human exposure to toluene II. Toluene in venous blood during and after exposure. Int Arch Occup Environ Health 1978;42:105-17.

6 Carlsson A, Ljungquist E. Exposure to toluene. Concentration in subcutaneous adipose tissue. Scand $J$ Work Environ Health 1982;8:56-62.

7 Konietzko H, Keilbach J, Drysch K. Cumulative effects of daily toluene exposure. Int Arch Occup Environ Health 1980;46:53-8.

8 von Döbeln W. Human standard and maximal metabolic rate in relation to fat-free body mass. Acta Physiol Scand 1956; 37(suppl 126):1-79.

9 von Döbeln W. Obesitas: II. Mätmetoder och nomenklatur. Läkartidningen 1960;57:2472-5.

10 Engström J, Bjurström R. Exposure to xylene and ethylbenzene II. Concentration in subcutaneous adipose tissue. Scand $J$ Work Environ Health 1978;4:195-203.

11 Ovrum P. The sampling of organic solvent vapors in air by motorpowered syringes. Am Ind Hyg Assoc J 1986;147:650-4.

12 BMDP statistical software, Los Angeles: Department of Biomethematics UCLA, 1981.

13 Astrand I. Uptake of solvents in the blood and tissue of man. A review. Scand J Work Environ Health 1975;1:199-218.

14 Steiner E, Iselius L, Alván G, Lindsten J, Sjöqvist F. A family study of genetic and environmental factors influencing polymorphic debrisoquine hydroxylation. Clin Pharmacol Ther 1985;38:394-402.

15 Åkesson B, Skerfving S, Mattiasson L. Experimental study on the metabolism of triethylamine in man. Br J Ind Med 1988;45: 262-8.

16 Wigaeus Hjelm E, Näslund PH, Wallén M. Influence of cigarette smoking on the toxicokinetics of toluene in man. $J$ Toxicol Environ Health 1988;25:155-63.

17 Waldron HA, Cherry N, Johnston JD. The effects of ethanol on blood toluene concentrations. Int Arch Occup Environ Health 1983;51:365-9.

18 Wallén $M$, Näslund PH, Byfält Nordqvist $M$. The effects of ethanol on the kinetics of toluene in man. Toxicol Appl Pharmacol 1984;76:414-9. 